\title{
Technological and morphological characteristics of acoustically assisted frozen "foie gras" (fattened duck liver)
}

\author{
Desislava Vlahova-Vangelova ${ }^{1 *}$, Desislav Balev ${ }^{1}$, Nikolay $\mathrm{Kolev}^{1}$, Rada Dinkova $^{2}$, Stefan Dragoev ${ }^{1}$ \\ ${ }^{1}$ Department of Meat and Fish Technology, Technological Faculty, University of Food Technologies, Plovdiv, Bulgaria \\ ${ }^{2}$ Department of Preservation and Refrigeration Technology, Technological Faculty, University of Food Technologies, Plovdiv, \\ Bulgaria
}

\begin{abstract}
The aim of this work was to explore the changes in morphology, $\mathrm{pH}$ and color characteristics ( $\mathrm{L}^{*}$, $a^{*}, b^{*}$ ) in AEF (Acoustic Extra Freezing) frozen fatty duck liver "foie gras" (LA) after 18 months of frozen storage $\left(-18^{\circ} \mathrm{C}\right)$. The cooled fattened duck liver $\left(0-4^{\circ} \mathrm{C}\right)$ was processed with acoustic assisted pre-massage step for $20 \mathrm{~min}$, followed by $\mathrm{AEF}$ freezing at $-25^{\circ} \mathrm{C}$ until reaching $-18^{\circ} \mathrm{C}$ in the center of the product. The conventionally air frozen "foie gras" (air temperature $-35^{\circ} \mathrm{C}$ ) were used as control (LK). The type of freezing did not affect significantly on the $\mathrm{pH}$ of the tested samples $(\mathrm{p} \geq 0.05)$. The changes in the instrumentally measured color characteristics $\left(\mathrm{L}^{*}, \mathrm{a}^{*}, \mathrm{~b}^{*}\right)$ in AEF frozen "foie gras" were found lower $(\mathrm{p} \leq 0.05)$ compared to LK. The light microscopy of LK frozen "foie gras" showed large ice crystals formation and significant destructive changes in muscles. After AEF freezing, the cell structure was better preserved, and histologically similar to fresh "foie gras".
\end{abstract}

\section{Introduction}

The growing demand for fresh meat necessitates the introduction of preservation methods that ensure high durability while maintaining the organoleptic and nutritional qualities of the product. Extending the shelf life of frozen food products is achieved by reducing the access of microorganisms to free water, which turns into ice at negative temperatures [1]. The freezing process is strongly influenced by the factors: thermal properties of the food (related to the thermodynamics of the freezing process), chemical composition, product size, distribution and size of ice crystals, as well as recrystallization during storage of frozen foods [2].

Widely used freezing methods as air blast freezing and plate contact freezing ongoing causing severe damage of muscle tissue due to low thermal conductivity and formation of large ice crystals [3]. Passing through the process of freezing, some of the characteristics of the meat undergo negative changes. The color of frozen food becomes darker, part of the muscle proteins denatures, their solubility and functional properties change, and ultimately its nutritional value decreases [5]. Ongoing oxidative changes not only in the protein but also in the lipid fraction are also a significant problem for the quality of frozen meat. With the formation of larger the ice crystals the damage to the cell structure is greater, resulting in significant losses of tissue juices after thawing [4].

In order to reduce the negative effects of food freezing, various innovative approaches to refrigeration processing are being developed. They aim is to improve the technological properties and preserve the organoleptic properties and nutritional value of frozen meat and fish products. Some of them are: cryogenic freezing, super chilling, acoustic freezing and others.

Acoustic freezing is an innovative technology using ultrasound that supports the process of crystal formation during freezing and is a "green" technology with high energy efficiency [6]. This innovative processing method has the potential to improve and accelerate the freezing process by slowing down oxidative changes without compromising food quality [7]. After fast freezing the damage to food structures is minimal by the producing of fine and uniform extra- and intra-cellular ice crystals [8].

Fattened duck liver is a highly valued product by consumers [10]. On the other hand, fatty duck liver is high in fat $(55-60 \%)$ and contains a large amount of heme iron. The risk of oxidative processes and deterioration of organoleptic characteristics of the product is very high [10].

As the preservation of fattened duck liver organoleptic characteristics is of paramount importance, its freezing is carried out very quickly with liquid nitrogen. The freezing process destroys cell structure in duck liver and increase the process of oxidation, promote the release of enzymes and haem iron [9]. The cavitation in ultrasound assisted freezing promote the formation of smaller ice crystal and fracturing large ice crystals [3]. Acoustic freezing of fattened duck liver is a potential alternative to the currently used liquid nitrogen freezing due to the fast process and simple equipment. Studies on the effect of acoustic freezing on cell structure and technological characteristics of meat products are insufficient and no data on acoustically frozen fattened duck liver is available.

Therefore, the aim of the present work is to establish the morphological and $\mathrm{pH}$ changes, as well as

\footnotetext{
* Corresponding author: desislava vangelova@abv.bg
} 
instrumentally recorded characteristics $\left(L^{*}, a^{*}, b^{*}\right)$ in acoustically frozen fattened duck liver after 18 months of frozen storage.

\section{Materials and methods}

The fattened duck liver from mule ducks (Cairina moschata x Anas Platyrhynchos, $90 \mathrm{~d}$ of age) was delivered from a slaughterhouse in the village of Brezovo, Republic of Bulgaria. Immediately after extraction, the liver was placed in flaky ice and transported in refrigerated conditions $\left(0-4^{\circ} \mathrm{C}\right)$. Some of the samples (L0) were examined immediately $\left(0-4^{\circ} \mathrm{C}\right.$, $2 \mathrm{~h}$ post mortem). To monitor changes in frozen state, 5 samples (150 - $200 \mathrm{~g}$ each) from the group (LK, LA), a total of 20 samples were frozen. Five frozen samples from each group were used at 6 and 12 months of storage $\left(-18^{\circ} \mathrm{C}\right)$. Mean samples were prepared and the analyzes were performed with the required number of replicates $(\mathrm{n}=5)$.

The fattened liver, intended for freezing, was cooled to $0-4^{\circ} \mathrm{C}$, placed in individual packages (vacuum bags) and frozen (LA) by acoustically assisted freezing. Vacuum packages with fatty duck liver are placed in a freezer (shock freezer cabinet with acoustic module AEF APACH SH05/SH20). The samples were subjected to pre-massage with acoustic waves $(20 \mathrm{~min}$, $3^{\circ} \mathrm{C},>500 \mathrm{~Hz}$ ), followed by acoustically assisted freezing at $-25^{\circ} \mathrm{C}$ until reaching $-18^{\circ} \mathrm{C}$ in the center of the product $(>500 \mathrm{~Hz})$ according to patent $\mathrm{WO}$ 2021/148721 A1.

Control samples (LK) were frozen intensively at $-35^{\circ} \mathrm{C}$ till reaching temperature of $-18^{\circ} \mathrm{C}$ in the center of the product. After freezing, the fattened liver (LA and LK) was stored for 12 months in a frozen $\left(-18^{\circ} \mathrm{C}\right)$ state.

The parameters of chilled $\left(0-4^{\circ} \mathrm{C}\right)$, six and twelve month frozen $\left(-18^{\circ} \mathrm{C}\right)$ stored fattened duck liver were studied.

Mean laboratory sample was prepared by homogenization, immediately after opening the packages ( $x$ five pieces for each examined period) of the defrosted to $1-3^{\circ} \mathrm{C}$ samples.

\subsection{Establishment of instrumentally evaluated colour characteristics}

The Konica Minolta colorimeter CR-410 (Konica Minolta Holding, Inc., Ewing, New Jersey, USA) was used to evaluate the brightness ( $\mathrm{L}^{*}$ value), the red component $\left(\mathrm{a}^{*}\right.$ value) and the yellow component $\left(\mathrm{b}^{*}\right.$ value) [11].

\subsection{Determination of $\mathrm{pH}$ value}

After homogenizing $10 \mathrm{~g}$ sample in $90 \mathrm{~mL}$ of distilled water, the $\mathrm{pH}$ of the samples was measured electro potentiometrically [12] with a $\mathrm{pH}$ meter Microsyst MS 2004 (Microsyst, Plovdiv), equipped with a temperature and combined $\mathrm{pH}$ electrode. The $\mathrm{pH}$ electrode is of the Sensorex Combination Recorder S 450 CD type (Sensorex pH Electrode Station, Garden Grove, CA, USA).

\subsection{Light microscopy}

Two $\mathrm{x}$ one $\mathrm{x}$ one $\mathrm{cm}$ samples were used for morphological analysis. The preparations were fixed with haematoxylin/ eosin. Fixation and contrast of the samples was performed according to the procedure described by Barbut et al. [13]. The analysis of the samples was performed using a microscope (Olimpus BX41TF, Japan), at a magnification of 400x.

\subsection{Statistical analysis}

The statistical analysis of mean values from the three replications is made. Variable analysis (Anova TwoFactor with Replication) with significance level $\mathrm{P} \leq 0.05$ was performed [14]. Differences between values lower than 0.05 are considered statistically significant [15]. All statistical procedures were performed using Microsoft Excel 5.0 software.

\section{Results and discussion}

\subsection{Changes in pH values of conventionally an acoustically frozen fattened duck liver during twelve months of frozen storage at $-18^{\circ} \mathrm{C}$.}

The established $\mathrm{pH}$ values (Table 1) of the fattened liver (L0) confirmed the early post mortem period in which it is located.

Table 1. $\mathrm{pH}$ values of duck liver after six and twelve months of frozen storage $\left(-18^{\circ} \mathrm{C}\right)$.

\begin{tabular}{|c|c|c|c|}
\hline Parameter & \multicolumn{3}{|c|}{ pH } \\
\hline Samples & LO & LK & LA \\
\hline $\begin{array}{l}\text { Chilled "Foie gras" } \\
2 \mathrm{~h} \text { post mortem } \\
\text { at } 0-4^{\circ} \mathrm{C}\end{array}$ & $5.50^{\mathrm{x}} \pm 0.03$ & & \\
\hline $\begin{array}{l}\text { "Foie gras" after } \\
6 \text { months frozen } \\
\text { storage at }-18^{\circ} \mathrm{C}\end{array}$ & & $6.50^{\mathrm{a}, \mathrm{y}} \pm 0.06$ & $6.40^{\mathrm{a}, \mathrm{y}} \pm 0.05$ \\
\hline $\begin{array}{l}\text { "Foie gras" after } \\
12 \text { months frozen } \\
\text { storage at }-18^{\circ} \mathrm{C}\end{array}$ & & $6.56^{\mathrm{a}, \mathrm{y}} \pm 0.03$ & $6.58^{\mathrm{a}, \mathrm{z}} \pm 0.03$ \\
\hline
\end{tabular}

a,b - index showing a statistically significant differences $(p<0.05)$ between the mean values by rows

$x, y$ - index showing a statistically significant differences $(p<0.05)$ between column averages

After six months of refrigerated storage $\left(-18^{\circ} \mathrm{C}\right)$, the $\mathrm{pH}$ increased significantly in both studied samples. The registered increase for the conventionally frozen fattened duck liver (LK) was $15.4 \%(\mathrm{p} \leq 0.05)$, and for the acoustic frozen (AL) liver was $14 \%(\mathrm{p} \leq 0.05)$.

After twelve months of frozen storage $\left(-18^{\circ} \mathrm{C}\right)$ the changes were less intensive, with an increase in LA liver of $2.74 \%(\mathrm{p} \leq 0.05)$. At the end of experiment (12 months, $-18^{\circ} \mathrm{C}$ ) no statistically significant differences in $\mathrm{pH}$ in conventionally frozen fattened duck liver (LK) were found.

According to the data obtained from the two-factor analysis of variance, the storage time had a significant effect on the $\mathrm{pH}$ of the ,foie gras" during twelve months of frozen storage at $-18^{\circ} \mathrm{C}$. The dependence is modeled 
by multiple regression. Since there is Significance $\mathrm{F}=$ $2.12^{-6}<0.05$, it can be concluded that the regression model is statistically significant (i.e., good) for the selected level of 0.05 .

The type of freezing did not have a statistically significant effect on the $\mathrm{pH}$ of the tested samples.

\subsection{Instrumentally measured colour characteristics $\left(L^{*}, a^{*}, b^{*}\right)$ of conventionally and acoustically frozen fattened duck liver during twelve months of storage at $-18^{\circ} \mathrm{C}$}

The formation of ice crystals during freezing changes the colour characteristics of frozen meat [2]. After 6 months of storage $\left(-18^{\circ} \mathrm{C}\right)$ the brightness $\left(\mathrm{L}^{*}\right)$ in the acoustically frozen "foie gras" (Table 2) increased by $1.33 \%$, while in conventionally frozen samples the increase was $2.68(\mathrm{p} \leq 0.05)$. Less evident changes in the $\mathrm{L}^{*}$ component after acoustic freezing is probably due to insignificant changes in cell structure [4].

As the shelf life of frozen meat increases, its color characteristics gradually deteriorate due to ongoing, although slow, biochemical processes [16]. Possible reasons for the decrease in the brightness of the colour after freezing are the denaturation of the proteins, the oxidation and last but not least the microbial activity. After 12 months of frozen storage $\left(-18^{\circ} \mathrm{C}\right)$, the brightness $\left(\mathrm{L}^{*}\right)$ of the acoustically frozen fattened duck liver (LA) decreased ( $\mathrm{p} \leq 0.05)$. The registered decrease in acoustically frozen "foie gras" was 7.9\% compared to the sixth month of storage $(p \leq 0.05)$. For the same period, after conventional freezing (LK), the $\mathrm{L}^{*}$ component decreased by $11.2 \%$. At the end of the experiment $\left(12\right.$ months, $\left.-18^{\circ} \mathrm{C}\right)$, the changes in the $\mathrm{L}^{*}$ component of the LA liver were less compared to conventional freezing $\left(-18^{\circ} \mathrm{C}\right)$.

In acoustic frozen (LA) and six-month refrigerated stored $\left(-18^{\circ} \mathrm{C}\right)$ samples, the changes red component $\left(\mathrm{a}^{*}\right)$ was not found to be statistically significant ( $p \geq 0.05)$. In contrast, in conventionally frozen samples (LK), the $a^{*}$ component decreased by $4.85 \%(p \leq 0.05)$. Frozen storage $\left(6\right.$ months, $\left.-18^{\circ} \mathrm{C}\right)$ had insignificant effect on the yellow component in acoustically frozen "foie gras"
(LA). The observed increase for the study period was $5.3 \%(\mathrm{p} \leq 0.05)$. By the end of the experiment $(12$ months, $-18^{\circ} \mathrm{C}$ ) the $b^{*}$ component in LA samples did not change $(p \geq 0.05)$. Compared to LA samples, after conventional freezing and 6 months' storage, the increase in $b^{*}$ component values was $10.7 \%(p \leq 0.05)$ and after 12 months at $-18^{\circ} \mathrm{C}$ the decrease in $b^{*}$ LK values was $8 \%(\mathrm{p} \leq 0.05)$.

According to the data from the two-factor analysis of variance (Anova Two-Factor with Replication), the storage time and the interaction of the two factors affect the value of $L^{*}(p \leq 0.05)$, but not the type of freezing. The two factors - storage time and type of freezing and their interaction affect the value of the $a^{*}$ and $b^{*}$ components $(\mathrm{p} \leq 0.05)$. The dependence is modelled by multiple regression. Since the Significance is $\mathrm{F}=$ $0.000316<0.05$, it can be concluded that the regression model is statistically significant (i.e., good) $(\mathrm{p} \leq 0.05)$.

A number of denaturation and oxidative changes occur in frozen meat [2]. As a result of all these processes, substances that degrade the color characteristics of the frozen product, are formed and accumulated [6]. The obtained results show that after acoustically assisted freezing the changes in the color characteristics $\left(L^{*}, a^{*}, b^{*}\right)$ are less $(p \leq 0.05)$ compared to the conventional freezing.

\subsection{Morphological changes in conventionally and acoustically frozen fattened duck liver ("foie gras")}

Light microscopy of the chilled liver (L0) shows a preserved structure of a classic liver particle (Fig.1). The cells have a preserved structure, the hepatocytes are radially located on hepatocyte lamellae. After conventional freezing and 6 months storage $\left(-18^{\circ} \mathrm{C}\right)$, significant destructive changes in the structure of the particles are observed (LK, 6 months). Ruptures in the cell structure of the formed ice crystals are established. For the same period, the changes after acoustically assisted freezing (LA, 6 months) and storage were less pronounced. The ice crystals formed are smaller in size and evenly distributed in the cell structure (Fig. 1).

Table 2. Changes in the brightness $\left(\mathrm{L}^{*}\right)$, red $\left(\mathrm{a}^{*}\right)$ and yellow $\left(\mathrm{b}^{*}\right)$ component of the color of duck fattened liver $(, f$ foie gras") after six and twelve months of frozen storage $\left(-18^{\circ} \mathrm{C}\right)$.

\begin{tabular}{|c|c|c|c|c|c|c|c|c|c|}
\hline Color characteristic & \multicolumn{3}{|c|}{$L^{*}$} & \multicolumn{3}{|c|}{$a^{*}$} & \multicolumn{3}{|c|}{$b^{*}$} \\
\hline Samples & L0 & LK & LA & LO & LK & LA & L0 & LK & LA \\
\hline $\begin{array}{l}\text { Chilled "Foie gras" } \\
2 \mathrm{~h} \text { post mortem } \\
\text { at } 0-4^{\circ} \mathrm{C}\end{array}$ & \multicolumn{3}{|c|}{$58.73^{x} \pm 0.39$} & \multicolumn{3}{|c|}{$14.27^{x} \pm 0.32$} & \multicolumn{3}{|c|}{$19.25^{x} \pm 0.34$} \\
\hline $\begin{array}{l}\text { "Foie gras" after } \\
6 \text { mounts frozen } \\
\text { storage at }-18^{\circ} \mathrm{C}\end{array}$ & & $60.30^{\mathrm{a}, \mathrm{y}} \pm 0.45$ & $59.52^{\mathrm{a}, \mathrm{y}} \pm 0.30$ & & $13.61^{\mathrm{a}, \mathrm{y}} \pm 0.02$ & $14.29^{\mathrm{b}, \mathrm{x}} \pm 0.20$ & & $17.39^{\mathrm{a}, \mathrm{y}} \pm 0.16$ & $18.28^{\mathrm{b}, \mathrm{y}} \pm 0.30$ \\
\hline $\begin{array}{l}\text { "Foie gras" after } \\
12 \mathrm{~m} \text { frozen storage } \\
\text { at }-18^{\circ} \mathrm{C}\end{array}$ & & $54.28^{\mathrm{a}, \mathrm{z}} \pm 0.31$ & $55.17^{\mathrm{b}, \mathrm{z}} \pm 0.33$ & & $21.19^{\mathrm{a}, \mathrm{z}} \pm 0.02$ & $22.44^{\mathrm{b}, \mathrm{y}} \pm 0.20$ & & $16.10^{\mathrm{a}, \mathrm{z}} \pm 0.04$ & $18.94^{\mathrm{b}, \mathrm{z}} \pm 0.38$ \\
\hline
\end{tabular}

a, b - index showing a statistically significant differences $(\mathrm{p}<0.05)$ between the mean values by rows

$\mathrm{x}, \mathrm{y}$ - index showing a statistically significant differences $(\mathrm{p}<0.05)$ between column averages 


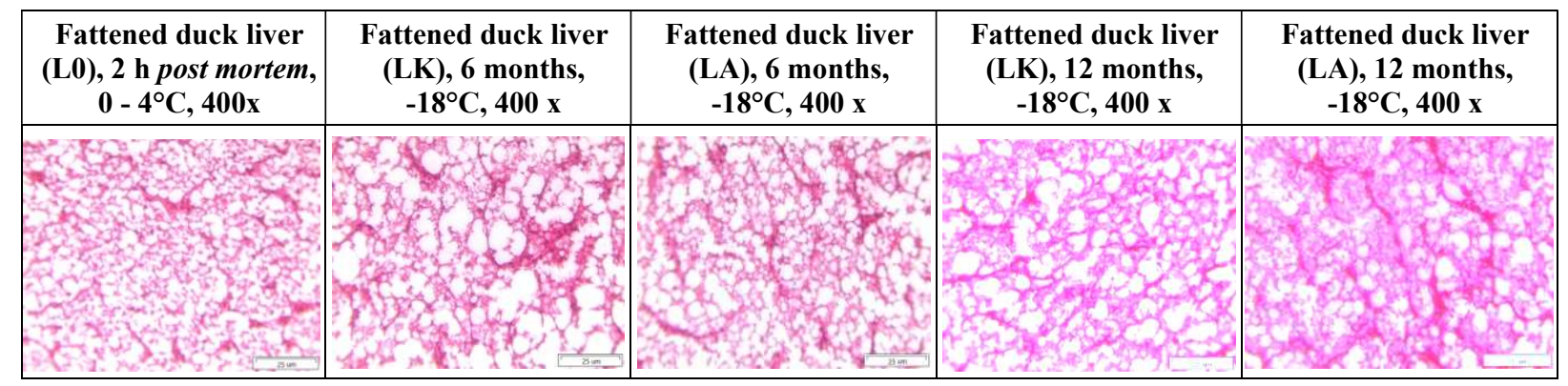

Figure 1. Light microscopy of duck fattened liver ("foie gras") $2 \mathrm{~h}$ post mortem and after six and twelve months of frozen storage $\left(-18^{\circ} \mathrm{C}\right)$, colored with haematoxylin eosin.

It is clear that the chemical composition and in particular the content of water, fat and connective tissue affect the changes that occur in frozen foods. Fat duck liver contains a large amount of fat $(50-60 \%)$, about $10 \%$ protein and $25-30 \%$ water [17]. Compared to muscle tissue the water content in fatty duck liver is lower $(70-75 \%)$ and suggests that the amount of ice crystals and damage in tissue will be less, too.

Changes in histology after 12 months storage are similar to those found at $6 \mathrm{~m}$. In acoustically frozen and stored 12 months ,foie gras" (LA, 12 months) the cell structure is better preserved.

The initiation of crystal formation in acoustically assisted freezing contributes to the maximum preservation of the cell structure in the native state [5].

The stability of heme pigments (hemoglobin and myoglobin) is greater and up to the sixth month of storage, the formation of their oxidized forms is negligible [3]. Probably for this reason, the red color in the acoustically frozen liver (LA, 6 and 12 months) has values close to those found in the chilled one (Table 2 ).

\section{Conclusions}

The type of freezing did not have a statistically significant effect on the $\mathrm{pH}$ of the tested samples. After acoustically assisted freezing, the changes in the instrumentally measured color characteristics $\left(\mathrm{L}^{*}, \mathrm{a}^{*}\right.$, $\left.b^{*}\right)$ are less pronounced $(p \leq 0.05)$ compared to those established in samples frozen using conventional freezing method. In conventionally frozen "foie gras", the formed large ice crystals cause significant tissue changes. In the samples examined after acoustically assisted freezing, the cell structure is better preserved, and histologically resemble those of the cooled "foie gras".

\section{References}

1. C. E. Coombs, B. W. Holman, M. A. Friend, D. L. Hopkins, Meat Sci. 125, 84-94 (2017)

2. M. Tan, J. Mei, J. Xie, Crystals. 11, 68 (2021)

3. W. Cheng, K. M. Sørensen, S. B. Engelsen, D. W. Sun, H. Pu, J. Food Eng. 263, 311-319 (2019)

4. Zhan, X., D. W. Sun, Z. Zhu, Q. J. Wang, Crit. Rev. Food Sci. Nutr. 58, 2925-2938 (2018)

5. N. Nakazawa, E. Okazaki, Fish. Sci. 86, 231-244 (2020)
6. A. D. Alarcon-Rojo, L. M. Carrillo-Lopez, R. Reyes-Villagrana, M. Huerta-Jiménez, I. A. GarciaGalicia, Ultrason. Sonochem. 55, 369-382 (2019)

7. D. Kang, W. Zhang, J. M. Lorenzo, X. Chen, Crit. Rev. Food Sci. Nutr. 61, 1914-1933 (2021)

8. Q. Sun, F. Sun, X. Xia, H. Xu, B. Kong, Ultrason. Sonochem. 51, 281-291 (2019)

9. L. Aubry, T. Sayd, C. Ferreira, C. Chambon, A. Vénien, S. Blinet, M. Bourin, A. Travel, M.Halgrain, V. Santé-Lhoutellier, L. Théron, Molecules. 26, 3508 (2021)

10. X. Fernandez, M. Bouillier-Oudot, C. Molette, M. D. Bernadet, H. Manse, Poultry Sci. 90, 2360-2369 (2011)

11. M. Hunt, A. King, Sh. Barbut, J. Claus, D. Cornforth, D. Hanson, AMSA Meat Colour Measurement Guidelines (American Meat Science Association, Champaign, 2012)

12. O. A. Young, J. West, A. L. Hart, F. F. H. Van Otterdijk, Meat Sci. 66, 493-498 (2004)

13. S. Barbut, Z. Zhang, M. Marcone, Poultry Sci. 84, 797-802 (2005)

14. N. R. Draper, H. Smith, Applied regression analysis Vol. 326 (John Wiley \& Sons., Hoboken, NY, 1998).

15. M. G. Kenward, J. R. Stat. Soc.: Ser. C. (Appl. Stat.) 36, 296-308 (1987)

16.Z. Zhu, Q. Zhou, D. W. Sun, Trends Food Sci. Technol. 90, 13-25 (2019)

17. M. F. Abu-Salem, A. E. Abou Arab, Grasas Aceit. 61, 126-135 (2010) 